\title{
MELAYANI KRISTUS DENGAN KARYA TULIS
}

\author{
Dr. Juanda, S.Sos. \\ Sekolah Tinggi Teologi Injili Indonesia Surabaya \\ E-mail:Juanda@sttii-surabaya.ac.id
}

Abstract. The title of this qualitative study is Serving Christ In Writing. In addition through the study of literature, in this study there were five informants interviewed are in Jakarta, Bandung, and Yogyakarta 1 person and then Surabaya 2 persons. Opinion of the five informants was not too much different. Essentially a writer needs to have the preparation of the material that will be presented. But since this is within the scope of Christianity, the good news that should not be forgotten for broadcast.

Keywords: Serving, Writing, Christianity, literature

\section{PENDAHULUAN}

Menulis merupakan suatu karya. Suatu karya sulit sekali untuk dinilai secara obyektif. Karena di dalam suatu hasil karya seni, maka yang ada adalah suatu keindahan untuk bisa dirasa. Dan penilaian yang boleh disodorkan itu merupakan kekuatan apresiasi baik secara positif maupun negatif semata. Inipun bersifat subyektif pula.Dan ketika telah merasakan indahnya suatu tulisan, baik secara isi maupun bahasanya, maka akan disusul suatu rangsangan untuk mengolahnya dalam otak untuk mengambil kesimpulan dari tulisan itu. Maka berarti tulisan itu telah menjadi sesuatu sumber kenikmatan bagi rasionya.

Terlepas daripada cara menikmati suatu karya tulis, maka seorang penulis tidak ada bedanya dengan seorang yang suka berbicara. Karena kalau hasil pembicaraan itu dikumpulkan dan dijilid, maka akan menghasilkan suatu buku. Namun di dalam penyampaiannya ada perbedaan di antara keduanya.

Dalam bahasa lisan, telah dipersiapkan dengan baik, yaitu perkataan-perkataan yang dirancang untuk telinga. Terkadang memang seseorang pandai menulis, namun ketika tampil sebagai pembicara sukar untuk dimengerti. Itu menunjukkan bahwa bahasa lisan berbeda dengan bahasa tulisan. ${ }^{1}$ Bahasa lisan lebih bersifat langsung, cenderung diulang, cenderung melupakan tata bahasa dan lebih pribadi.

${ }^{1}$ Juanda. Diktat Kuliah STII, Ilmu Komunikasi, Suatu Pengantar Untuk Sekolah Teologi, 16-20.
Selain itu harus memenuhi beberapa syarat, yaitu kata-katanya harus jelas, tak asing, pendek, tepat, sesuai, terkini, menggunakan kalimat sempurna, aktif, spesifik dan retorik. ${ }^{2}$

Sedangkan dalam bahasa tulis memiliki syarat yang berbeda. Tidak sepenuhnya seperti syarat bahasa lisan, meskipun dalam beberapa hal sama. Dalam bahasa tulis, tidak bisa diulang-ulang secara langsung untuk menjelaskan sesuatu hal. Sehingga terkesan akan menimbulkan kalimat yang panjang. Selain itu, tidak akan bisa langsung mengharapkan tanggapan dari pembaca.Namun dalam bahasa tulis, lebih akan menghadirkan suatu tulisan yang bermakna dan lebih akurat dalam penjelasannya. Karena sang penulis tidak perlu lagi untuk tergesagesa dalam menyusun tulisannya, alias ada tenggang waktu untuk memperbaiki isi dan tata bahasanya, sehingga hasil dari tulisan itu akan mudah untuk dimengerti.

Maka sebenarnya, untuk menjadi seorang penulis tidak terlalu sulit seperti yang dibayangkan. Penulis, merupakan suatu profesi yang sebenarnya paling mudah dilakukan.di muka bumi ini. Karena sejak mulai bisa menulis, maka saat itu sebenarnya sudah menjadi penulis. Tinggal bagaimana melakukan perangkaian akan kata-kata yang ada, kemudian timbul menjadi sebuah kalimat. Dan kalau kalimat-kalimat itu dirangkai dengan aneka ilustrasi, dan memiliki arti yang berkesinambungan

\section{${ }^{2}$ Ibid.}


antara satu dengan yang lainnya, maka jadilah sebuah kisah. Dan kalau kisah-kisah yang sepenggalsepenggal itu diatur sedemikian rupa akan bisa membentuk sebuah bab-bab di dalam buku. Dan dari kumpulan bab-bab itu jika dibumbui dengan aneka ilustrasi yang enak untuk dilihat, maka jadilah sebuah buku. Namun inipun tergantung sekali di tangan siapa sebuah kisah itu berada. Karena mau tidak mau, hasil akhir suatu tulisan juga dipengaruhi sekali oleh karakter dan motivasi dari sang penulisnya. Sehingga sebelum menampilkan tulisannya, seharusnya dikoreksi kembali, apakah tidak akan menyakiti hati Allah?

\section{KARAKTERISTIK MEDIA CETAK}

Menjadi penulis tidaklah terlalu sulit. Namun bila seorang penulis salah menulis, akan bisa menjadi boomerang yang menyakitkan. Selain tidak laku dijual, karena tidak ada peminatnya, juga kalaupun dibaca tidak akan menjadi berkat bagi para pembacanya. Laksana menjadi gembala yang tidak mengenal dombanya, yaitu yang menjadi sasaran dari tulisan itu.Dalam hal tanggungjawabnyapun, maka seorang penulis rohani sungguh besar, karena untuk meralat suatu kesalahan memerlukan waktu yang sedikit lebih lama dibanding dengan media massa elektronik. Meskipun persiapannya dengan sangat mantap, namun tidak akan mencapai sasaran yang diharapkan.Oleh sebab itu, pengenalan akan karakteristik sebuah media cetak sangatlah penting. Kesalahan yang fatal, akan mengakibatkan kerugian baik moral maupun material. Dan ujung-ujungnya akan bisa menciptakan generasi gereja yang tidak suka membaca.

Pemilihan sebuah media cetak sebagai medianya, harus disesuaikan dengan situasi dan kondisi masyarakat yang menjadi target dari pesan tersebut. Jika lokasinya di pedalaman mungkin lebih efisien kalau berbentuk terbitan bulanan atau berupa buku.Maka saat akan melayani Kristus dengan karya tulis tetap memerlukan kepekaan itu. Penyajian tulisan yang berwawasan Amanat Agung harus dikemas sedemikian rupa sehingga tidak menggurui apalagi memerintah. Namun memberikan pemaparan yang menggugah hati sehingga berkesan. Menyajikan wawasan yang membuat pembacanya menjadi cerdas dalam beriman, sehingga memiliki data-data yang akurat sebelum mengambil suatu keputusan rohani.

\section{MENGEMBAN AMANAT AGUNG}

Ketika seseorang telah percaya dan menerima Kristus Yesus sebagai Tuhan dan Juruselamatnya secara pribadi, maka sisa kehidupannya yang ada, wajib diisi dalam kenikmatan dan sukacita untuk bisa senantiasa menceritakan nilai dari darahNya yang telah tercurah di bukit Golgota itu bagi dirinya.

Karena di dalam kisah tentang darah itu, ada suatu kisah kasih yang tidak rasionil bagi otak manusia sejagad raya. Maka bagi umat tebusanNya yang telah menerima kasih yang tercurah dari surga itu, timbul keharusan untuk bisa membagikannya dalam perbuatan dikesehariannya. Kasih yang telah dimiliki dalam hatinya itu harus terpancar untuk bisa mengasihi Tuhan Allah, sesama dan diri sendiri. Itulah yang terurai dengan jelas di dalam Amanat Agung kasih yang terlukis dalam Matius 22:37-39. Dan melalui penjelasan arti kasih itu dalam tulisan, maka akan membuat pembaca mendapatkan berita baru bahwa ada kasih yang luar biasa dahsyatnya.

Sedang dalam Matius 28:19a berkata: "Karena itu pergilah, jadikanlah semua bangsa murid-Ku ... ."3 Sedangkan KJV menterjemahkan: "Go ye, therefore, and teach all nations, ... ." Menurut kamus Inggris-Indonesia, teach diterjemahkan mengajar dan melatih. ${ }^{5}$

Ada kemiripan arti, yang tetap mempunyai misi, supaya setiap orang dijadikan seperti yang diharapkan oleh Tuhan Yesus. Dalam hal ini Tuhan Yesus ingin setiap orang melakukan apa yang telah diperintahkanNya. Dan segala perintahNya itu perlu disebarluaskan.

"Tetapi bagaimana mereka dapat berseru kepadaNya, jika mereka tidak percaya kepada Dia? Bagaimana mereka dapat percaya kepada Dia, jika mereka tidak mendengar tentang Dia. Bagaimana mereka mendengar tentang Dia, jika tidak ada yang memberitakanNya? Dan bagaimana mereka dapat memberitakanNya, jika mereka tidak diutus? Seperti

${ }^{3}$ Matius 28:19a.

${ }^{4}$ The New Scofield Reference Bible With Concordance and New Oxford Bible Maps, (New York: By Oxford University Press, Inc. 1967).

${ }^{5}$ Drs. Peter Salim, M.A., Advanced EnglishIndonesion Dictionary, (Jakarta: Modern English Press, 1 Juni 1993). 
ada tertulis; "Betapa indahnya kedatangan mereka yang membawa kabar baik!" jelas Rasul Paulus dalam Roma 10:14-15.

Pemberitaan akan kabar sukacita baik tentang kasih maupun Kristus adalah tugas setiap orang percaya. Ada berbagai cara dalam penyampaiannya. Yang begitu fasih bisa langsung dengan tatap muka. Namun ada juga yang memerlukan dukungan sebuah media atau sarana di dalam penyampaiannya.

Dalam hal ini, media yang paling sederhana adalah media cetak. Media yang berisi tulisan dalam bentuk cetakan untuk penduplikasiannya. Melalui media ini, beritanya bisa langsung menerjang para penerimanya di samping melalui kesaksian hidup seseorang. Media cetak tidak memiliki perasaan malu atau takut, tatkala menyampaikan sebuah berita.

Media cetak hanya sebuah benda yang dikemudikan oleh mesin yang hidup yaitu manusia. Layaknya seorang sopir yang cakap, maka setiap penumpangnya akan selamat sampai di tujuan. Namun perlu diperhatikan pula kondisi mobilnya yang menjadi media angkutannya.Sedang salah satu ciri yang paling khas dalam proses penyampaian informasi adalah persiapan untuk dipilih. Dan tak pernah pengalaman dua orang yang manapun akan tepat sama. ${ }^{6}$ Oleh sebab itu, dalam memformat sebuah media cetak sangatlah penting, jikalau ingin dipergunakan sebagai media siar Injil. Kesalahan didalam mendesain bentuknya, akan membuat suatu kelemahan pula.

\section{RUMUSAN MASALAH}

Bagaimana memulai suatu tulisan dan membuat sebuah tulisan yang bisa memiliki pengaruh kerohanian bagi pembacanya, khususnya yang tulisan yang bernuansa Kasihsentris dan Kristosentris? Serta bentuk tulisan yang bagaimana yang bisa menarik minat baca para jemaat Tuhan? Banyak sekali orang ingin menjadi penulis rohani yang profesional. Namun seringkali terbentur dalam merangkai ide cerita yang dituangkan dalam alam tulisan. Padahal di angan-angan dalam kepala sudah ada. Apakah yang harus dilakukannya sehingga bisa menghasilkan suatu bentuk tulisan yang kreatif

${ }^{6}$ D. Lawrence Kincaid dan Wilbur Schramm, Azas-azas Komunikasi Antar Manusia, (Jakarta: LP3ES bekerja sama dengan East-West Communication Institute, 15 Mei 1977), 11.

\section{TUJUAN DAN KEGUNAAN}

Pertama. Tujuan: (a) Untuk mengetahui kehandalan dan karakteristik seorang penulis rohani serta media cetaknya. Sehingga dalam mempersiapkan sebuah tulisan untuk sebuah media cetak akan bisa mengenai sasarannya; (b) Merangsang seseorang untuk terbeban menjadi penulis rohani yang bernuansa Kasihsentris dan Kristosentris; (c) Supaya sang penulis rohani bisa menyajikan tulisan yang bisa menggembalakan pembacanya, sehingga para pembaca akan mendapatkan tulisan yang menyegarkan jiwanya serta senantiasa ditunggu-tunggu kemunculannya.

Kedua. Kegunaan: (a) Memberikan semangat akan manfaat dunia penulisan bagi yang ingin berkarier menjadi penulis rohani, baik pemula atau yang memperluas cakrawala kepenulisan; (b) Membekali para penulis dalam mengembangkan tulisannya; (c) Menunjukkan keefektifan sebuah tulisan di dalam mempengaruhi opini masyarakat; (d) Menunjukkan bahwa dengan media massa cetak, maka bisa menjangkau daerah tertentu yang tertutup bagi misionaris; (e) Bahwa orang introvert atau tertutup yang biasanya lebih menyukai media cetak tertentu, akan bisa terkena biasnya.

\section{METODOLOGI}

Melalui studi kepustakaan yang berhubungan dengan teologi, kepenulisan, jurnalistik, sosiologi, psikologi, kebudayaan, komunikasi, media massa cetak serta dilanjutkan dengan mewawancarai informan. Lalu menganalisanya untuk mendapatkan intisari dari masing-masing disiplin ilmu dan pendapat informan tersebut, kemudian merangkumkannya untuk bisa menjawab rumusan masalah yang ada.Analisis Kualitatif - Deskriptif

Dalam Habakuk 2:2 dikatakan: "Tuliskanlah penglihatan itu dan ukirkanlah itu pada loh-loh, supaya orang sambil lalu dapat membacanya." Ini menunjukkan sekali bahwa menulis itu merupakan hal yang penting bagi Allah. Sehingga dengan inisiatifnya sendiri, Allah memerintahkan Habakuk membuat layaknya sebuah dokumentasi yang bisa dibaca kelak oleh generasi berikutnya. Sehingga ini membuktikan bahwa kekuatan sebuah berita akan lebih dahsyat kalau diukir pada loh-loh (sebuah media). Bisa dikenang dan dinikmati lagi suatu saat lain. Bahkan, dalam pemikiran Allah bahwa jika ada 
orang yang lewat sambil lalu saja, dapat membacanya juga. Itu berarti, ada saat tertentu baik ditengah kesibukan atau kesendirian seseorang, ternyata masih bisa diterpa oleh sebuah berita yang sangat penting. Sehingga keberadaan suatu berita itu tidak hanya dibatasi saja pada saat penyampaiannya, namun juga bisa mengalami suatu penundaan penerimaan.

Sehingga proses berkomunikasi dalam kekristenan, bukanlah sesuatu yang kabur atau tidak jelas. Komunikasi itu terasa dekat, karena terlihat, terdepan dan terasakan. ${ }^{7}$ Oleh sebab itu, maka dalam menulis, harus memikirkan tingkat penerimaan dari penerima pesan tersebut.Ketika Allah berkomunikasi dengan manusia, senantiasa menggunakan metode yang paling mudah, supaya bisa diterima oleh manusia. Allah mengetahui keterbatasan bahasa dan tingkat pengertian seorang anak manusia yang paling cerdas sekalipun.Dan Rasul Yohanespun menuliskan dalam 1 Yohanes 1:1,4 yang menguraikan runtutan peristiwa karya keselamatan Allah seperti ini:

"Apa yang telah ada sejak semula, yang telah kami dengar, yang telah kami lihat dengan mata kami, yang telah kami saksikan dan yang telah kami raba dengan tangan kami tentang Firman hidup, itulah yang kami tuliskan kepada kamu. Dan semuanya ini kami tuliskan kepada kamu, supaya sukacita kami menjadi sempurna."

Ada kepuasan tersendiri bagi Rasul Yohanes setelah menuliskan berita itu. Bukan sekedar kepuasan namun suatu sukacita yang menjadi sempurna. Apalagi kalau ia tahu bahwa tulisannya itu telah dibukukan dan dibaca hingga di pedalaman wilayah Indonesia.Tulisan sebagai media siar Injil, memiliki arti yang sangat penting. Meskipun Rasul Paulus, menurut sejarah melakukan perjalanan sejauh $\pm 9000 \mathrm{~km}$ dengan jalan kaki atau berlayar dengan kapal-kapal kecil untuk memberitakan Injil, ${ }^{8}$ namun ia tetap menulis surat kepada jemaat-jemaat yang telah dikunjungi atau yang belum dikunjungi sebanyak 13 buah surat.

Berbagai media, telah Allah pakai sebagai sarana penyampaian berita kasihNya. Sejak zaman

\footnotetext{
${ }^{7}$ Marior Van Horne, Tulislah Apa Yang Kau Lihat, (Jakarta: PT. BPK Gunung Mulia, 1985), 1.

${ }^{8}$ William Barclay, Duta Bagi Kristus (Latar Belakang Peta Perjalanan Paulus), (Jakarta: PT. BPK Gunung Mulia, 1985), 3.
}

Perjanjian Lama hingga Perjanjian Baru ada aneka bahan yang digunakan sebagai media suatu tulisan. Dan melalui Alkitab itulah terkumpul seluruh pesan cinta kasihNya yang merupakan media cetak terakhir yang dipakai oleh Allah untuk seluruh umat ciptaanNya.

Kisah sejarah sekitar 6000 tahun yang lalu, tentang peristiwa penciptaan alam semesta hingga karya keselamatan dalam Kristus Yesus Tuhan, bisa dinikmati hingga saat ini, untuk dipelajari dan dipahami. Ternyata media ini, yaitu Alkitab benarbenar dijaga oleh tangan Allah sendiri di dalam bergelut menghadapi tantangan zaman.

Sedang dalam dunia Islam, menurut Ismail Hamid dalam Arabic and Islamic Literary Tradition menyatakan kehebatan berdakwa melalui pidato ( $A l$ Khitabah) dan penulisan surat (Al-Risalah) adalah sumber komunikasi sejak awal perkembangan dan kebangkitan Islam. Sepeninggal nabi Muhammad SAW, metode dakwah melalui tulisan atau penulisan surat dakwah terus dikembangluaskan oleh para sahabat nabi, pemimpin dan cendikiawan muslim. ${ }^{9}$ Dengan demikian, kiprah seorang penulis rohani, memiliki peran yang sangat penting dalam menyampaikan berita yang tertuang dalam Amanat Agung. Baik Amanat Agung yang memberitakan Kabar Kasih maupun memberitakan Kabar Baik demi kemuliaan Allah dan kebaikan sesama.

Arti mengasihi itu sangat penting di dalam dunia kekristenan. Ini ditegaskan dalam Matius 22:37-39, yang menjelaskan bahwa di dalam hukum kasih maka tergantung seluruh hukum Taurat dan kitab para nabi. Ini penyataan universal yang tidak akan ditemui di kitab agama manapun juga.

Jawab Yesus kepadanya: "Kasihilah Tuhan, Allahmu, dengan segenap hatimu dan dengan segenap jiwamu dan dengan segenap akal budimu. Itulah hukum yang terutama dan yang pertama. Dan hukum yang kedua, yang sama dengan itu, ialah : Kasihilah sesamamu manusia seperti dirimu sendiri."

Sedangkan kalau hanya bersandar kepada kasih saja, maka akan mengarah kepada sekedar hal yang bersifat moralitas atau teologi sosial. Tidak ada pemberitaan bahwa dibalik itu, Allah yang lebih

\footnotetext{
${ }^{9}$ Sutirman Eka Ardhana, Jurnalistik Dakwah, (Yogyakarta: Pustaka Pelajar, 1995), 31-32.
} 
dahulu mengasihi manusia dengan mengorbankan AnakNya yang tunggal. Supaya setiap orang yang percaya dan menerimaNya sebagai Tuhan dan Juruselamatnya memiliki kepastian keselamatan.

edangkan, di dalam hukum kasih, itu hanya merupakan penyadaran awal tentang keberadaan manusia yang sungguh bernilai untuk bisa mengasihi Allah, sesama dan diri sendiri. Dan itu menjadi tidak berguna jikalau orang itu tidak di dalam Tuhan.Oleh sebab itu, maka tugas memberitakan Kabar Kasih dan Kabar Baik menjadikan suatu puncak yang harus senantiasa didengung-dengungkan. Kerinduan seorang penulis rohani yang mengasihi Tuhan ingin sekali menggenapi pula perkataan Yesus dalam Matius 28:19-20. "Karena itu pergilah, jadikanlah semua bangsa muridKu dan baptislah mereka dalam nama Bapa dan Anak dan Roh Kudus, dan ajarlah mereka melakukan segala sesuatu yang telah Kuperintahkan kepadamu. Dan ketahuilah, Aku menyertai kamu senantiasa sampai kepada akhir zaman."Meskipun perintah di situ lebih menekankan pekerjaan yang dilakukan oleh utusan Injil, dalam hal ini, seorang manusia, namun untuk menjadikan semua bangsa muridKu dan mengajar segala sesuatu yang telah Kuperintahkan sangat bisa dilakukan melalui karya tulis.

Suatu ketika, Charles Haddon Spurgeon melayani seorang wanita tua di Inggris, yang hampir mati karena sakit keras. Seperti biasanya pembukaannya adalah memberitakan keselamatan dalam Kristus. Namun wanita tua itu berkata, "Saya telah memiliki Juruselamat dalam Tuhan Yesus."

Dan sebagai seorang yang Injili, kemudian Charles H. Spurgeon tetap ingin memastikan akan keselamatan jiwa si wanita. Kemudian si wanita itu mengeluarkan secarik kertas yang telah kumal bekas dipakai sebagai pembungkus. Lalu diberikan kepada Charles H. Spurgeon. Ketika dibaca ternyata di dalamnya berisi berita tentang keselamatan di dalam Kristus Yesus Tuhan. Setelah dibaca dengan teliti ternyata kertas kumal itu terbitan Amerika. Tetapi si wanita itu menerimanya dari Australia. Ini merupakan sesuatu peristiwa yang tidak bisa dinalar sebelum peristiwa itu terjadi pada saat itu. Bahwa ada sesuatu kekuatan perlindungan pada pembawa pesan-pesan surgawi untuk fokus tertentu. Ternyata sebuah berita keselamatan yang dicetak pada kertas itu, telah berlayar di atas kapal menjelajahi 3 benua, yaitu Amerika, Australia dan bersandar di Eropa pada tangan seseorang yang sungguh-sungguh membutuhkan isi pesan dari berita itu menjelang ajalnya.

Namun yang tak dapat dikerjakannya adalah membaptis. Bagaimana suatu tulisan yang benda mati bisa membaptis? Ini, bagi penganut teologi yang tidak menganut baptisan simbolistik melalui air, tidak masalah. Karena memang hakikat keselamatan hanya dengan percaya dan menerima Yesus sebagai Tuhan dan Juruselamat secara pribadi. Kemudian dengan sekejap Allah akan membaptisnya dalam Roh Kudus ke dalam tubuh Kristus. Sekejap pula namanya tercatat pada buku kehidupan di surga.

Tetapi bagi teolog yang menekankan sekali proses simbolistik melalui pembaptisan air, akan sangat bermasalah. Tapi terlepas daripada perdebatan tak bermanfaat itu, maka fungsinya sebagai media yang interaktif bisa dijalankan, yaitu dengan membantu menghubungi sebuah gereja di sekitarnya. Lalu dibaptislah ia.

Lalu dalam ilustrasi di atas, yang ditugaskan untuk pergi adalah beritanya. Berita tidak pernah memiliki rasa takut atau malu. Ia akan menuju kepada sasaran yang teracak. Tak ada satupun yang bisa menahan lajunya berita itu. Semua halanganhalangan akan diterjang, karena pada prinsipnya bahwa Firman tidak akan kembali dengan sia-sia. Terlebih daripada itu, dengan melalui media tulisan, maka penyebarannya akan bisa sangat cepat dan ekonomis. Juga memiliki kemampuan untuk mengatasi berbagai hambatan-hambatan yang ada, baik itu hambatan alam maupun yang dibuat dengan sengaja oleh tangan manusia. Ternyata, sebuah berita tertulis memiliki kekuatannya tersendiri untuk mengatasi hambatanya sendiri.

Hal ini, tampak sekali pada perjuangan penginjilan lewat media cetak di Rusia. Surat kabar Komunis memuat berita bahwa tukang daging Kristen turut menyebarkan agama Kristen dengan menyelipkan traktat-traktat Kristen dalam kertas pembungkus daging yang mereka jual. Pers Komunis juga menyebutkan bahwa orang-orang Kristen yang bekerja di percetakan Komunis, menyelinap masuk pada malam hari untuk mencetak ribuan literatur Kristen, dan menguncinya kembali sebelum matahari terbit. Pers Komunis menyebutkan pula bahwa anak-anak Kristen di Moskow telah menerima Injil dari beberapa sumber, 
lalu menyalin bagian-bagiannya dengan tulisan tangan. Kemudian anak-anak itu memasukkan salinan-salinan itu dalam saku mantel guru-guru mereka, yang digantung di lemari sekolah. ${ }^{10}$

Ini sebuah kisah nyata akan kekuatan pengaruh dari sebuah media cetak. Siapa yang berani terangterangan menginjil di daerah Komunis? Hanya media cetak, karena tentu media elektronik yang berada di sana, di bawah pengawasan yang sangat ketat dari pemerintah Komunis. Dan hanya media cetak adalah media yang paling mudah untuk digunakan sebagai sarana mengemban misi Amanat Agung.

\section{Teknik Pengumpulan Data}

Data dikumpulkan melalui studi kepustakaan, yaitu yang sesuai dengan pokok-pokok permasalahan yang sedang dibahas dan melengkapinya dengan data-data pendukung yang relevan dengan pokokpokok permasalahan tersebut dan wawancara para informan.

\section{Sampel Sumber Data}

Obyek yang akan diteliti oleh peneliti adalah penulis Kristen yang berada Jakarta 1 orang, Bandung 1 orang, Yogyakarta 1 orang dan Surabaya 2 orang. Karena penelitian ini menggunakan pendekatan penelitian bersifat kualitatif, maka peneliti akan menentukan 5 informan itu, yang akan diwawancarai untuk mewakili penulis Kristen lainnya. Untuk mendapatkan data yang diperlukan dalam penelitian ini, peneliti akan mempergunakan teknik pengambilan sampel sumber data dengan purposive sampling.

Purposive Sampling adalah teknik pengambilan sampel sumber data dengan pertimbangan tertentu. Pertimbangan tertentu ini, misalnya orang tersebut yang dianggap paling tahu tentang apa yang kita harapkan, atau mungkin dia sebagai penguasa sehingga akan memudahkan peneliti menjelajahi obyek / situasi sosial yang diteliti. $^{11}$

Sedangkan Suharsimi Arikunto mengatakan terkait Purposive Sampel bahwa:Sampel bertujuan dilakukan dengan cara mengambil subjek bukan

${ }^{10}$ Richard Wurmbrand, Berkorban Demi Kristus, (Surabaya: Yayasan Kasih Dalam Perbuatan, 2001), 113-114.

\footnotetext{
${ }^{11}$ Sugiyono. Metode Penelitian Kuantitatif Kualitatif Dan R\&D. 218-219.
}

didasarkan atas strata, random atau daerah tetapi didasarkan atas adanya tujuan tertentu. Teknik ini biasanya dilakukan karena beberapa pertimbangan, misalnya alasan keterbatasan waktu, tenaga, dan dana sehingga tidak dapat mengambil sampel yang besar dan jauh. ${ }^{12}$

Dalam hal ini, Riduwan. menyebutnya juga dengan istilah sampling pertimbangan.

Purposive Sampling dikenal juga dengan sampling pertimbangan ialah teknik sampling yang digunakan peneliti jika peneliti mempunyai pertimbangan-pertimbangan tertentu di dalam pengambilan sampelnya atau penentuan sampel untuk tujuan tertentu. Hanya mereka yang ahli yang patut memberikan pertimbangan untuk pengambilan sampel yang diperlukan. Oleh karena itu, sampling ini cocok untuk studi kasus yang mana aspek dari kasus tunggal yang representatif diamati dan dianalisis. ${ }^{13}$

Untuk memperoleh kedalaman dan keluasan materi yang disajikan, serta validitas data yang diperoleh, maka pemilihan seorang informan menjadi sesuatu yang sangat penting. Apabila dikaitkan dengan tujuan pemilihan informan ini, perlu juga diperhatikan tujuan penelitiannya. Teknik ini digunakan apabila anggota sampel yang dipilih secara khusus berdasarkan tujuan penelitian. ${ }^{14}$

Menyusun Pedoman Wawancara

Peneliti menyusun pedoman wawancara yang didasarkan pada kerangka teori yang telah ada, supaya tidak terjadi penyimpangan dari tujuan penelitian semula yang telah ditetapkan. Maka dalam penelitian ini ada 4 pertanyaan inti sebagai pedoman wawancara, yang kemudian dilengkapi dengan sub-sub pertanyaan lisan, yaitu:

Pertama. Bagaimana memulai suatu tulisan dan membuat sebuah tulisan yang bisa memiliki pengaruh kerohanian bagi pembacanya, khususnya yang tulisan yang bernuansa Kasihsentris dan Kristosentris? Kedua. Bagaimana yang bisa menarik minat baca para jemaat Tuhan?

Ketiga. Apa yang harus dilakukan seorang penulis, sehingga bisa menghasilkan suatu bentuk tulisan yang kreatif?

\footnotetext{
${ }^{12}$ Suharsimi Arikunto. Prosedur Penelitian. (Jakarta: PT Rineka Cipta, 2010), 183.

${ }^{13}$ Riduwan. Belajar Mudah Penelitian.

(Bandung: Alfabeta, 2011), 63.

${ }^{14}$ Husaini Usman \& Purnomo Setiady Akbar. Metodologi Penelitian Sosial. 45.
} 


\section{PEMBAHASAN}

Menulis merupakan bagian yang begitu erat berkaitan dengan perkembangan peradaban kebudayaan manusia. Suatu budaya akan menjadi berkembang pesat kalau dalam komunitasnya bisa memberikan sumbangsih yang jelas dalam berbagai aneka tulisannya. Tentu saja tanpa sebuah tulisan, maka ada berbagai hal yang telah disepakati bersama, tidak akan bisa dinikmati oleh generasi yang mendatang.

Apalagi bagi peradaban modern, maka ketrampilan untuk bisa menulis telah sedikit dipaksakan bagi mereka yang memiliki usia di bawah lima tahun (balita) sekalipun. Dengan harapan suatu kelak ketrampilan yang telah dimulai sedini mungkin itu, akan membekali sang anak memiliki kecerdasan semaksimal mungkin tatkala ikut andil berkarya dalam menikmati perkembangan pengetahuan yang ada.

Dan selanjutnya, tentu saja dengan adanya usaha memulai kebiasaan untuk cinta atau senang menulis menjadi berkembang dikemudian hari yang akan menghantarnya menjadi seorang penulis yang bermanfaat bagi sekitarnya. Ini tentu bukan suatu proses pembelajaran yang akan sekejap jadi. Namun ada proses yang berkesinambungan untuk bisa senantiasa belajar dan belajar.

Apalagi jikalau seseorang telah mengalami jamahan kasih dari Allah dalam Kristus Yesus Tuhan, akan terjadi gejolak dalam hati ingin sekali bisa membagikan kasih itu kepada sesamanya. Tentu saja salah satu caranya dalam menyebarkan pengaruh kasih itu dengan berkarya melalui karya tulis.

Seseorang yang telah memiliki kasih Kristus, itu bisa menjadi sumber inspirasi utamanya di dalam setiap karya tulisnya. Dengan demikian, maka setiap pembacanya akan mengetahui bahwa sang penulisnya memiliki Kristus di dalam hatinya. Dengan bimbingan Roh Kudus, maka karya tulisnya itu akan memiliki pengaruh yang dahsyat bagi para pembacanya.

Tentu saja, ini tidak akan begitu saja terjadi. Karena dibutuhkan kemauan untuk menulis, mengembangkan dan senantiasa membenahi setiap kekurangan yang ada sehingga karya yang disajikan itu memiliki kualitas yang diharapkan. Maka tak ada jalan lain dalam melakukannya, yaitu harus terjun langsung memulainya tanpa menunda-nunda. Seperti saran Rasul Paulus dalam Efesus 5:16 yang berkata,
"Dan pergunakanlah waktu yang ada, karena harihari ini adalah jahat."

Karena memang pada dasarnya, semua orang bisa menulis. Cuma masalahnya malas melakukannya. Menulis hanyalah pengganti cara penyampaian isi pikiran dan hati yang ingin sekali dituangkan. Dan cara penuangannya kali ini dengan tulisan. Tak bedanya seseorang yang lagi kasmaran, akan menyampaikan surat cintanya berhalaman-halaman banyaknya. Kalau andai tiap bulan bisa menyusun sepuluh halaman surat cinta, maka setahun akan berjumlah seratus duapuluh halaman. Awal sebuah novel kisah cinta sudah terbayang di depan mata.

Memang ada berbagai alasan seseorang mau menulis. Bisa hanya sekedar menyalurkan hobi atau bahkan merupakan panggilan hidup. Bisa juga untuk dijadikan sebagai mata pencaharian dan terlebih lagi adalah menjadi sebuah sarana untuk memuliakan nama Tuhan.

Memuliakan nama Tuhan melalui tulisan, sungguh ini dikenan sekali di hadapan Tuhan. Karena ketika motivasi seorang penulis terarah untuk memuliakan nama Tuhan, tentu itu akan menjadi berkat bagi pembacanya. Tak ayal, ada dua keuntungan yang akan digapai oleh tulisan jenis ini.

Karena melaluinya akan mendapatkan suatu karya tulis yang bernuansa kasih, yaitu mengasihi Allah, sesama dan diri sendiri, dan atau juga untuk menjelaskan dengan tegas bahwa keselamatan hanya ada di dalam diri Kristus Yesus Tuhan. Seperti yang diungkapkan oleh tabib Lukas dalam Kisah Para Rasul 4:12 bahwa, "Dan keselamatan tidak ada di dalam siapa pun juga selain di dalam Dia, sebab di bawah kolong langit ini tidak ada nama lain yang diberikan kepada manusia yang olehnya kita dapat diselamatkan."

Seorang penulis rohani memiliki peranan yang besar sekali di dalam mengemban misi Amanat Agung. Oleh sebab itu, selayaknyalah di setiap tulisannya, akan selalu terinspirasi untuk menceritakan misi yang sedang diembannya itu. Tentu saja, tidak semaunya sendiri di dalam penyampaiannya.

Ada dua cara di dalam penyampaian Kabar Kasih dan Kabar Baik yang senantiasa bernuansa Kristosentris, yaitu menjelaskannya secara tersirat atau tidak tegas dan yang tersurat, yaitu penuh dengan ketegasan. Secara teologis, yang tersirat biasa diistilahkan Indirect Evangelism dan yang tersurat adalah Direct Evangelism. 
Keduanya tetap merupakan penginjilan melalui tulisan. Namun untuk menjangkau sesuatu yang peka dan bisa menimbulkan konflik, maka lebih bijaksana kalau pembahasaannya dengan tersirat. Di sinilah kepiawaian seorang penulis tertantang. Bahkan ayat Alkitabpun tidak dicantumkan. Yang dicantumkan adalah isi dari ayat itu. Maka artikel atau buku yang dihasilkan bisa menjadi konsumsi semua pihak. Tapi nilai-nilai kekristenan ada di dalamnya. Dengan demikian, ini akan menjadi suatu batu loncatan untuk menggebrak kebekuan hati yang senantiasa ingin menolak keberadan Allah yang sejati dalam Kristus Yesus Tuhan.

Dan setelah terbiasa dengan peristilahan yang ada dalam Firman Allah, Alkitab, maka suatu kelak laksana akibat suatu terpaan iklan di TV, akan mencuat di saat-saat tertentu dalam situasi tertentu kerinduan untuk mencari kebenaran. Maka sekarang yang dibutuhkan adalah suatu artikel atau buku yang menjelaskan dengan sejelas-jelasnya isi dari Alkitab.

Selain itu juga, setelah menanamkan nilai-nilai kekristenan, maka juga sebuah tulisan yang rohani juga bisa menjadi suatu bentuk corong kebenaran yang hakiki. Memang banyak kebenaran yang dianggap kebenaran di dalam dunia ini. Namun semuanya itu bersifat subyektif.

Lalu apakah sebenarnya kebenaran itu? Dalam Yohanes 14:6 mengulas, "Kata Yesus kepadanya: "Akulah jalan dan kebenaran dan hidup. Tidak ada seorang pun yang datang kepada Bapa, kalau tidak melalui Aku." Inilah penyataan sejati satu-satunya di atas permukaan bumi yang berani menunjuk diri atau mengklaim diri sebagai kebenaran (aletheia). Dan terlebih hebatnya, kebenaran di sini bisa menghantar seseorang yang mempercayaiNya bertemu dengan Bapa di surga.

Sedang seorang Ketua Departemen Filsafat di Wheaton College, Illinois, Amerika Serikat, Arthur F. Holmes, Ph.D., berpegang pada proposisinya yang mengatakan bahwa segala kebenaran, di manapun itu ditemukan, bersumber dari Allah. Dengan kata lain, segala kebenaran adalah kebenaran Allah (All Truth is God's Truth). ${ }^{15}$

Maka, pemberitaan akan kebenaran senantiasa harus berpusatkan pada pribadi Kristus. Meskipun ketika menuliskannya dengan maksud palsu maupun jujur, harus tetap memberitakan sesuatu yang berpusat pada Kristus. Sehingga tulisan itu memiliki bobot yang layak untuk dibaca oleh setiap orang yang ingin mendapatkan kebenaran yang sejati.

Tetapi alangkah indahnya, jikalau mau menuliskan akan suatu tema, namun tetap dengan penuh kesadaran dan tanggungjawab kepada Allah dan manusia. Dengan demikiasn, selain tulisan itu berbobot, juga akan menumbuhkan sikap rohani sang penulisnya dari hari kesehari menuju kedewasaan ke arah Kristus.

Jadi, untuk menjadi seorang penulis rohani yang sejati, selain persiapan secara pengetahuan, maka kerohaniannyapun perlu diasah terus menerus. Kemudian menulis dan menulis. Sehingga setiap ide yang dituangkan dalam tulisan akan senantiasa memiliki beban untuk mengemban misi Amanat Agung yang telah dipercayakan di setiap pundak umat tebusan-Nya.

\section{KESIMPULAN}

Pendapat kelima informan itu tidak terlalu berbeda jauh. Intinya seorang penulis perlu memiliki persiapan tentang materi yang akan disajikannya. Namun karena ini adalah dalam lingkup kekristenan, maka berita sukacita itu tidak boleh dilupakan untuk disiarkan.

Selanjutnya perlu terus mengasah diri untuk tetap mempertahankan kreativitas yang dimilikinya. Ide tulisan, sesungguhnya banyak beredar di sekeliling kita. Namun bagaimana menangkapnya dan mengolahnya, itu tentu membutuhkan ketrampilan tersendiri. Maka perlu senantiasa latihan, latihan dan latihan.
${ }^{15}$ Arthur F. Holmes, Segala Kebenaran Adalah Kebenaran Allah, (Surabaya: Penerbit Momentum, 2000), 62. 


\section{KEPUSTAKAAN}

Alkitab. Jakarta: Lembaga Alkitab Indonesia, 1993.

Ardhana, Sutirman Eka. Jurnalistik Dakwah.

Yogyakarta: Pustaka Pelajar, 1995.

Arifin, Drs. Anwar. Strategi Komunikasi. Bandung: CV. Armico, 1984.

Arnold, Glenn. Writing Award Winning Articles.

New York: Thomas Nelson Publishers,1979.

Assegaff, Dja'far H. Jurnalistik Masa Kini. Jakarta:

Ghalia Indonesia, 1983.

Atmowiloto, Arswendo. Mengarang Itu Gampang. Jakarta: PT Gramedia, 1984.

Atmowiloto, Arswendo. Mengarang Novel Itu Gampang. Jakarta: PT. Gramedia, 1984.

Baggini, Julian. Making Sense. Jakarta: Penerbit Teraju, 2003.

Barclay, William. Duta Bagi Kristus (Latar Belakang Peta Perjalanan Paulus). Jakarta: PT. BPK Gunung Mulia, 1925.

Barna, George. The Power of Vision. California: Regal Books, 1992.

Blake, Reed H. dan Edwin O. Haroldsen. A Taxonomy od Concepts In Communication. New York: By Hostings House, Publisher, Inc, 1979.

Bono, Edward De. Mengajar Berpikir. Jakarta: Penerbit Erlangga, 1990.

Bunga Rampai. Visi Pelayanan Literatur. Yogyakarta: Yayasan Andi, 1989.

Covey, Stephen R. The Seven Habits of Highly Effective People. New York: Simon \& Schusters, 1989.

Diponegoro, Mohammad. Yuk, Nulis Cerpen Yuk. Yogyakarta: Shalahuddin Press, 1985.

Dwipayana, Aqua. Kiat Menulis Di Media. Jakarta:Global Mahardika Publication, 2003.

Engel, James F. Contemporary Christian Communications, Its Theory And Practice. New York: Thomas Nelson Publishers, 1979.

Fraser, Lindsey. Wawancara Dengan J.K. Rowling Si Pencipta Harry Potter. Jakarta: Penerbit Gramedia Pustaka Utama, 2004.

Graham, Billy. Beritakan Injil. Bandung: Lembaga Literatur Baptis, Yogyakarta: Yayasan Andi, 1992.

Halim, Nasim. Jurus Pintar Kartunis. Jakarta: PT. Gramedia Pustaka Utama, 2004.

Haqani, Luqman. Mengatasi 25 Hambatan Menulis. Bandung: Pustaka Ulumuddin, 2004.
Hardjodipuro, Dr. Siswojo. Karya Ilmiah. Jakarta: penerbit Erlangga, 1982.

Hart, Michael H. Seratus Tokoh Yang Paling Berpengaruh Dalam Sejarah. Jakarta: Pustaka Jaya, 1992.

Hensley, Dennis E. - Rose A.Adkins. Writing for Religious and Other Specialty Markets. Tennessee: Broadman Press, 1987.

Hesselgrave, David J. Communicating Christ Cross Culturally. Michigan: Zondervan Publishing House, 1978.

Holmes, Arthur F. Segala Kebenaran adalah Kebenaran Allah. Surabaya: Penerbit Momentum, 2000.

Horne, Marion Van. Tulislah Apa Yang Kau Lihat. Jakarta: PT. BPK Gunung Mulia, 1985.

Juanda, S.Sos. Diktat Kuliah, Ilmu Komunikasi, Suatu Pengantar Untuk Sekolah Teologi. Surabaya: STII - Surabaya, 2003.

Juanda. 777 Ungkapan Abadi. Yogyakarta: Andi, 2004.

Juanda, S. Sos., M.A. Iman Yang Berwawasan. Bandung: Kalam Hidup, 2006.

Juanda. 1111 Ungkapan Abadi. Yogyakarta: Andi, 2006.

Juanda. Pedoman Membuat Warta Gereja \& Artikel Renungan. Yogyakarta: Gloria Graffa, 2008.

Junaedhie, Kurniawan. Ensiklopedi Pers Indonesia. Jakarta: PT Gramedia Pustaka Media, 1991.

Kincaid, D. Lawrence dan Wilbur Schramm. Azasazas Komunikasi Antar Manusia. Jakarta:

LP3 ES bekerja sama dengan East-West Communication Institute, 15 Mei 1977.

Koesworo, F.X., J.B. Margantoro, Ronnie S. Viko. Di Balik Tugas Kuli Tinta. Surakarta: Sebelas Maret University Press dan Yogyakarta: Yayasan Pustaka Nusatama, 1994.

Kusnawan, Aep. Berdakwah Lewat Tulisan. Bandung: Mujahid Press, 2004.

Mappatoto, Andi Baso. Teknik Penulisan Feature (Karangan Khas). Jakarta: Gramedia Pustaka Utama, 1992.

Mueller, Lavonne \& Jerry D. Reynolds. Creative Writing, Forms and Techniques. Illinois: National Textbook Company, 1992.

Mulyana, Deddy. Ilmu Komunikasi, Suatu Pengantar. Bandung: PT. Remaja Rosdakarya, 2002. 
Mungo, Ray. Pedoman Menulis Otobiografi. Jakarta: Pustaka Tangga, 1999.

Nadeak, Wilson, Drs. Bagaimana Menjadi Penulis Artikel Kristiani Yang Sukses. Bandung: Yayasan Kalam Hidup, 1989.

Nasution, Nancy. Anda Mau Jadi Pengarang?. Jakarta: BPK Gunung Mulia, 1984.

Natawidjaja, P. Suparman. Bimbingan Cakap Menulis, Tehnik Mengarang Fiksi dan Non Fiksi. Jakarta: BPK Gunung Mulia, 1979.

Ngafuan, Muh. Memburu Uang Dengan Jurnalistik. Solo: CV. Aneka, 1995.

Novakovich, Josip. Berguru Kepada Sastrawan Dunia. Bandung: Kaifa, 2003.

Packer, J.I. Evangelism and The Sovereignty of God. Illinois: InterVarsity Press, 1961.

Poerwadarminta, W.J.S. Kamus Umum Bahasa Indonesia. Jakarta: Balai Pustaka, 1986.

Poerwantana, PK. Teknik Penulisan Timbangan Buku. Semarang: Aneka Ilmu, 1984.

Pranata, Xavier Quentin. Menulis Dengan Cinta. Yogyakarta: Yayasan Andi, 2002.

Pratt Jr, Richard L. Menaklukkan Segala Pikiran Kepada Kristus. Malang: Seminari Alkitab Asia Tenggara, 1994.

Rakhmat, Jalaludin, Drs., M.Sc. Psikologi Komunikasi. Bandung: Remadja Karya CV., 1986.

Salim, Peter, Drs., M.A. Advance EnglishIndonesian Dictionary. Jakarta: Modern English Press, 1993.

Sanyoto, Tri Priyo, Ir., M.Div., Eriana Sanyoto, Drh., M.Si. Metodologi Penelitian dan Penulisan Makalah. Surabaya: Sekolah Tinggi Theologia Injili Indonesia, 2001.

Scheer, Robert (ed.), Pengantar: Fidel Castro. HariHari Terakhir Che Guevara. Yogyakarta: Penerbit Narasi, 2004.

Siregar, Ras. Bahasa Indonesia Jurnalistik. Jakarta: Pustaka Grafika, 1987.

Situmorang, Drs. BP. Puisi, Teori Apresiasi Bentuk dan Struktur. Flores: Nusa Indah, 1983.

Soehoet, Drs. A.M. Hoeta. Dasar-Dasar Jurnalistik. Jakarta: Penerbit Yayasan Kampus Tercinta IISIP, 2003.

Sukidi. New Age, Wisata Spiritual Lintas Agama. Jakarta: PT Gramedia Pustaka Utama, 2002.

The New Scofield Reference Bible With Concordance and New Oxford Bible Maps. By Oxford University Press, Inc. 1967.

Tindas, Pdt. Dr. Arnold, M.Div. Diktat Kuliah. Bibliologi Kritik, 2000.
Verwer, George. Dinamika Pelayanan Literatur. Jakarta: Yayasan Obor Menyuluh, Surabaya: Yakin, 1995.

Webster's New World Dictionary. New York: Prentice Hall, 1989.

Wurmbrand, Richard. Berkorban Demi Kristus. Surabaya: Yayasan Kasih Dalam Perbuatan, 2001. 